\title{
Leprosy in Croatia in the twentieth century
}

\author{
ANDRIJA STANIMIROVIĆ*, MIHAEL SKERLEV*, \\ PETAR GAĆINA†, TEODORA BECK*, TONC̆I \\ STIPIĆ $\ddagger \&$ ALEKSANDRA BASTA-JUZBAS̆IĆ* \\ * Department of Dermatology and Venereology, Medical School of \\ Zagreb University and University Hospital Centre S̆alata, 41000 \\ Zagreb, Croatia; †Community Health Centre 'Petar Vitezica', \\ 58000 Split, Croatia; and $\$$ Medical Centre Vukovar, Croatia
}

\section{Accepted for publication 19 June 1995}

Summary Even today, leprosy is a relatively frequently occurring disease, especially in tropical regions of the world. From the eleventh to thirteenth century, leprosy pandemics affected Europe, including Croatia. Probably as a consequence of such history, one can still find endemic foci of leprosy in presentday Croatia.

The aim of this study was to analyse all cases of leprosy registered in Croatia during the twentieth century; therefore, we studied thoroughly existing medical documentation and published reports on sporadic leprosy cases, and went on to collect the relevant data through on-site investigation in those parts of Croatia known as putative endemic foci of leprosy. In this way, we collected data concerning the number of leprosy cases, the probable sources of infection, and traced the possible paths of spread of the disease.

During the twentieth century, 17 cases of leprosy were registered in Croatia. However, due to the loss of medical documentation concerning the cases from Metković, the total number was obviously slightly greater. Concerning the 17 analysed cases, 4 patients were most probably infected during their visits (as sailors or immigrant workers) to the Middle East, South America or Africa; 3 patients developed leprosy after prolonged close contact with previously infected family members, while the exact source of infection remains unsettled for the remaining 10. However, 2 of these patients originated from the area of Cazin in Bosnia and Herzegovina, which is known to be an endemic focus of leprosy. Furthermore, the remaining 8 came from the small area of the village of Blizna in the Croatian municipality of Trogir, and therefore it seems reasonable to conclude that Blizna represents the endemic focus of leprosy in Croatia. The last case of leprosy in Blizna was registered back in 1956. Nevertheless, it is clear that sporadic cases of leprosy can reappear in Croatia, originating either from this endemic focus of Blizna, or as an infected person returning to Croatia from abroad. So, we can conclude that, even today, Croatian medical doctors (and especially dermatovenereologists) should still be acquainted with the clinical diagnosis of leprosy and basic principles of its treatment. 


\section{Introduction}

Taking into consideration social and psychological aspects of leprosy, one can expect that many cases go unnoticed and, therefore, that the real number of people presently affected is not always easy to estimate. ${ }^{1,2}$ Leprosy occurs mostly in tropical regions, especially in equatorial and western Africa, southwest Asia, Oceania, Pacific islands, and Central and South America. It is generally believed that leprosy has occurred only sporadically in Europe since the First World War; however, the World Health Organization recorded 25,000 cases of leprosy in 1985, predominantly in Spain, Malta and Rumania. ${ }^{3}$

In Croatia, leprosy represents a less fortunate part of its historical heritage. It was already noted in Croatian regions (especially in Dalmatia) during the eleventh to thirteenth centuries as a consequence of the pandemic during the Crusades. Soon after that, leprosaria were established along the Croatian coast; the first in 1272 in Dubrovnik, followed by those in Zadar, Split, C̆iovo and Kotor. ${ }^{5}$ During the first half of the fourteenth century, the incidence of leprosy declined for the simple reason that most sufferers succumbed to plague (leprosy patients are especially vulnerable to secondary infections). The epidemic of leprosy reappeared significantly in Croatian regions after the Turkish conquest of the Balkan peninsula during the fifteenth and sixteenth centuries. ${ }^{4,5}$ As a consequence, some endemic foci of leprosy can be found even today in the Republic of Bosnia and Herzegovina, and they were until recently observable even in some parts of the Republic of Croatia. ${ }^{6}$

The aim of this study is to analyse all leprosy cases registered in Croatia during the twentieth century, on the basis of available data as well as our own field research. We would like to stress the importance of clinical diagnosis in leprosy, because even today the disease can appear sporadically in 'hidden' foci within Croatia; furthermore, cases can come to Croatia from abroad.

\section{Patients and methods}

We have studied the number of leprosy cases as well as the sources and routes of spread of the infection in Croatia for the period from 1900 to 1994 . We carefully collected and analysed all published sporadic cases of leprosy and then went on to collect information on leprosy patients within the former endemic foci in our country.

\section{Results}

The results of this study are summarized in Table 1 and Figure 1 . In the following paragraphs, we offer a concise chronological description of registered cases of leprosy.

A small focus of leprosy was noted in 1924 in the village of Vidonja (the municipality of Metković), but unfortunately the complete documentation concerning these patients was subsequently lost. However, in 1904, the local governmental report from Zadar reports on the examination of one 64-year-old leprosy patient from the village of Vidonja, and thus indirectly confirms the existence of that endemic focus. ${ }^{5}$

The leprosy focus in the village of Blizna (the municipality of Trogir) was registered 
Table 1. Leprosy cases in Croatia during twentieth century

\begin{tabular}{|c|c|c|c|c|c|}
\hline $\begin{array}{l}\text { Source and route } \\
\text { of inf ection }\end{array}$ & $\begin{array}{l}\text { Total } \\
\text { No. }\end{array}$ & Year & Patients & Age (yr) & Place \\
\hline $\begin{array}{l}\text { Leprosy from } \\
\text { foreign countries }\end{array}$ & 6 & $\begin{array}{l}1930 \\
1939 \\
1956 \\
1963 \\
1984 \\
1986\end{array}$ & $\begin{array}{l}\text { sailor } \\
\text { mason } \\
\text { sailor } \\
\text { student } \\
\text { housewife } \\
\text { housewife }\end{array}$ & $\begin{array}{l}76 \\
39 \\
55 \\
22 \\
63 \\
58\end{array}$ & $\begin{array}{l}\text { Brseć } \\
\text { Krk } \\
\text { Gornji Okrug } \\
\text { Zagreb } \\
\text { Ogulin* } \\
\text { Zagreb* }\end{array}$ \\
\hline $\begin{array}{l}\text { Close contact } \\
\text { with patients }\end{array}$ & 3 & $\begin{array}{l}1930 \\
1930\end{array}$ & $\begin{array}{l}\text { wife } \\
\text { two sons }\end{array}$ & $\begin{array}{l}68 \\
6,14\end{array}$ & $\begin{array}{l}\text { Brseć } \\
\text { Krk }\end{array}$ \\
\hline Endemic area Blizna & 8 & $\begin{array}{l}1927 \\
1956 \\
1956\end{array}$ & $\begin{array}{l}6 \text { members of a family } \\
\text { man } \\
\text { man }\end{array}$ & $\begin{array}{l}7,12,17,12,21, ? \\
46 \\
23\end{array}$ & $\begin{array}{l}\text { Blizna } \\
\text { Blizna } \\
\text { Blizna/Prgomet }\end{array}$ \\
\hline Endemic area Metković & $?$ & 1924 & medical records lost & & Vidonja/Metković \\
\hline
\end{tabular}

* Two cases from endemic area Cazin in Republic of Bosnia and Herzegovina.

in 1927, and 10 years later those cases were described in an article published in a Croatian medical journal Liječnički vjesnik. ${ }^{7}$ Leprosy was diagnosed in six members (3 boys and 3 girls) of the same family. The girls were aged 7, 12 and 17 years, respectively, and they were confined to the leprosarium in Sarajevo (Bosnia and Herzegovina) where they subsequently died; the fate of one boy was unknown, the other died at home at the age of 12, while the third died in the leprosarium in Sarajevo at the age of 21. The leprosarium in Sarajevo (Bosnia and Herzegovina) was the only one in former Yugoslavia. It was established in 1894 by Austrian dermatologists Glück \& Fleger. ${ }^{6}$ Even today, the village of Blizna is small and quite isolated which, together with our information collected on the spot, suggests that it was a real endemic focus of leprosy. It may be noted that, back in 1927, very strict measures were imposed by the local government, in an attempt to confine the infection to the village of Blizna, e.g. the police prevented anybody from leaving the village.

In 1930, leprosy was diagnosed in a 76-year-old fisherman and his 68-year-old wife in the village of Brseć (the municipality of Rijeka). ${ }^{8}$ On questioning the patient disclosed that as a sailor he had visited Syria and Lebanon several times and then retired when he was aged 50. Although the first signs of leprosy appeared 20 years later, it was concluded that the patient was infected during his voyages as a sailor, and that his wife was infected through repeated close contact with him; however, no signs of leprosy were noted in other family members. ${ }^{8}$

In 1939, leprosy was also diagnosed in 3 members of one family (father and two sons) in the village of Županja on the island of Krk. ${ }^{9}$ The man (aged 39) was formerly employed as a mason in South America, where he was engaged in building a leprosarium in Buenos Aires; he reported that on this occasion he was in close contact with local leprosy patients and that about 5 years after he returned to his home in Croatia he noted a loss of tactile sense and the appearance of 'bumps and nodules' on his hand and face. ${ }^{9}$ Several years later, he died in the leprosium in Sarajevo. Leprosy was also diagnosed in his two sons, aged 6 and 14; however, their further fate is unknown. It has to be noted that their mother showed no signs of leprosy. 


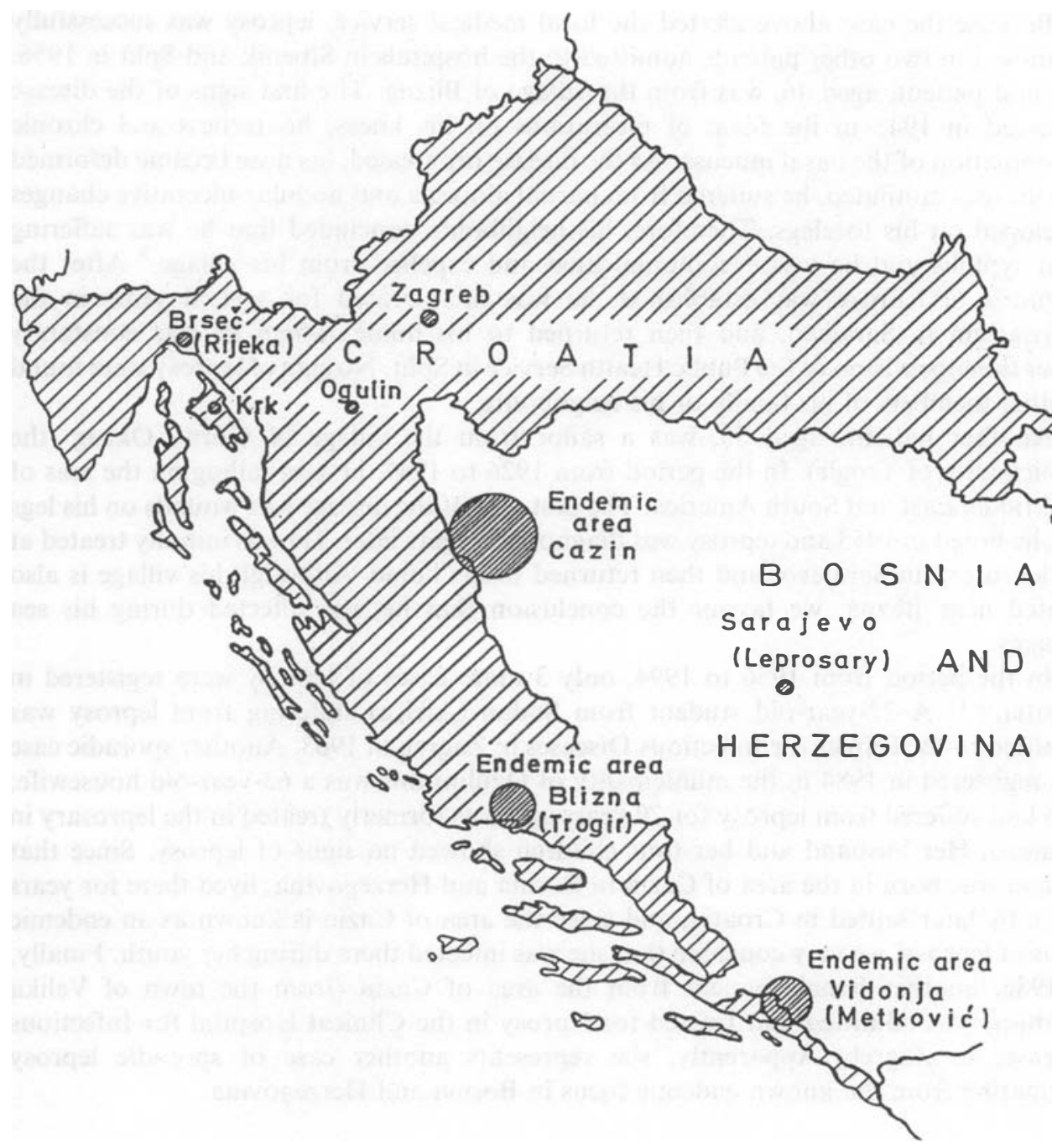

Figure 1. Leprosy in Croatia in 20th century.

The first case of leprosy in Croatia after the Second World War was diagnosed in Sibenik in $1956 .^{5}$ The patient, aged 23, was from the village of Prgomet (the municipality of Trogir); he noted polyps and ulcerations in his nose back in 1950, but at first he was treated as a typical case of tertiary syphilis. Two years later, he was admitted to hospital in Šibenik, and, interestingly enough, the first suspicion that he was suffering from leprosy was not raised by medical doctors but by a hospital guard who had previously seen some leprosy patients in Metković. Consequently, the diagnosis was soon established and the patient was transported to the leprosarium in Sarajevo, where he died several years later. As the village of Prgomet is situated in the close vicinity of the village of Blizna (mentioned above as an apparent endemic focus of leprosy), we believe that he was infected in the village of Blizna. 
Because the case above alerted the local medical service, leprosy was successfully diagnosed in two other patients admitted to the hospitals in Šbenik and Split in 1956. The first patient, aged 46, was from the village of Blizna. The first signs of the disease appeared in 1943 in the form of ulcerations on his knees, hoarseness and chronic inflammation of the nasal mucosa. As the disease progressed, his nose became deformed and his toes mutilated, he suffered from partial alopecia and nodular-ulcerative changes developed on his forelegs. Therefore, his neighbours concluded that he was suffering from syphilis and he was excommunicated and expelled from his village. ${ }^{5}$ After the diagnosis of leprosy was established, he was first treated for several years in the leprosarium in Sarajevo, and then returned to his home, where he was constantly under the supervision of the Public Health Service in Split. No sign of leprosy were found in other members of his family or his neighbours.

Another patient, aged 55, was a sailor from the village of Gornji Okrug (the municipality of Trogir). In the period from 1926 to 1947, he was sailing on the seas of the Middle East and South America. The first sign of the disease was wounds on his legs that he noted in 1953 and leprosy was diagnosed 3 years later. He was initially treated at the leprosary in Sarajevo, and then returned to his home. Although his village is also located near Blizna, we favour the conclusion that he was infected during his sea voyages.

In the period from 1956 to 1994 , only 3 more cases of leprosy were registered in Croatia. ${ }^{10,11}$ A 22-year-old student from Sudan (Africa) suffering from leprosy was admitted to the Clinics for Infectious Diseases in Zagreb in 1963. Another sporadic case was registered in 1984 in the municipality of Ogulin; this was a 63-year-old housewife, who had suffered from leprosy for 20 years and was formerly treated in the leprosary in Sarajevo. Her husband and her four children showed no signs of leprosy. Since that woman was born in the area of Cazin in Bosnia and Herzegovina, lived there for years and only later settled in Croatia, and since the area of Cazin is known as an endemic focus of leprosy, we may conclude that she was infected there during her youth. Finally, in 1986, another female patient from the area of Cazin (from the town of Velika Kladuša) was admitted and treated for leprosy in the Clinical Hospital for Infectious Diseases in Zagreb. Apparently, she represents another case of sporadic leprosy originating from the known endemic focus in Bosnia and Herzegovina.

\section{Discussion}

During the twentieth century, 17 cases of leprosy were diagnosed in Croatia. The exact number of cases from Metković is unknown, because their medical documentation was subsequently lost. Four patients were most probably infected by leprosy during their journeys or stays in the Middle East, South America or Africa. Three patients were infected due to prolonged and close contact with family members previously infected by leprosy in the above-mentioned parts of the world. For the remaining 10 patients, we were not able to determine the exact source of infection, and noted no suspicious contacts with other leprosy patients. Two of these patients originated from the area of Cazin, known as an endemic focus of leprosy in Bosnia and Herzegovina, while the remaining 8 patients all came from the area of the village of Blizna in the Croatian municipality of Trogir. Furthermore, clinically recognizable cases of leprosy in this area 
appeared at widely separated time intervals (30 years or more). Therefore, we conclude that the area of Blizna may be designated as an endemic focus of leprosy in Croatia. Finally, both the presence of very few cases of leprosy at that endemic focus as well as the total lack of leprosy symptoms and signs in most members of their families, support the conclusion that the contagiousness of leprosy is quite low (3-6\%), as already noted in the literature. ${ }^{3}$

\section{Conclusion}

The Department for Protection of Health of the Republic of Croatia has noted no cases of leprosy since 1986. However, our retrospective analysis of existing medical documentation as well as our in-field pilot epidemiological study clearly show that sporadic cases of leprosy can and do periodically appear in Croatia, either as a consequence of the arrival of infected patients from abroad or, more importantly, due to the existence of hidden endemic foci of leprosy within Croatia. Therefore, Croatian medical practitioners, and especially those in the field of dermatovenereology, should be acquainted with the clinical presentation of leprosy and the basic principles of its diagnosis and treatment.

\section{References}

${ }^{1}$ McDougall AC, Yawalkar SJ. Leprosy. Basic information and management. CIBA-GEIGY Limited 1987, Basle, Switzerland: 5-12.

2 Noordeen SK. A look at world leprosy. Lepr. Rev. 1991; 62: 72-86.

${ }^{3}$ WHO Study Group. Epidemiology of leprosy in relation to control. WHO Technical Report Series 1985; No. 716, Geneva.

4 Čulić M. Leprosy. Obavještenja, Rijeka 1963; 6: 389-400. (in Croatian).

5 C̆ulić M. The leprosy cases in Dalmatia. Obavještenja, Rijeka 1962; 5: 33-40. (in Croatian).

6 Glück L. Lepra in Bosnien und Herzegowina. In: Intern Dermat Congress II/2. Hirschwald, Berlin, 1905.

7 Peričić B. On one leprosy focus in Middle Dalmatia. Liječ Vjesn 1937; 59: 264-66. (in Croatian).

8 Bonetić N. The leprosy cases in Croatian Seaside. Liječ Vjesn 1931; 53: 789-92. (in Croatian).

9 Vukas A. The leprosy focus in a village on the island of Krk. Liječ Vjesn 1940; 62: 259-60. (in Croatian).

10 Archives of the Department for the Protection of Health of the Republic of Croatia-The Epidemiological Service. 1994, Zagreb (in Croatian).

11 Curl A. 30. Anniversary of the World's Day of Leprosy. Acta Derm Iug 1984; 11: 103-9. (in Croatian). 